УДК: 378.14+378.18

DOI: 10.37026/2520-6427-2021-107-3-127-134
Марина ШЕПЕЛЬ,

кандидат педагогічних наук, стариий викладач кафедри іноземних мов Одеського начіонального технологічного університету, м. Одеса, Украӥна ORCID: 0000-0001-6534-9797 email: marinashepel@gmail.com

\title{
РОЛЬ КУРАТОРА АКАДЕМІЧНОЇ ГРУПИ У СТАНОВЛЕННІ МАЙБУТНІХ ФАХІВЦІВ ГОТЕЛЬНО-РЕСТОРАННОЇ СПРАВИ ЯК ПРОФЕСІОНАЛІВ
}

Анотація. У статті окреслено роль куратора академічної групи у становленні майбутніх фахівців готельно-ресторанної справи як професіоналів. Проаналізовано погляди вітчизняних та зарубіжних науковців стосовно феномена кураторства, функиіи та якостей куратора, критерїв ефективності управління системою виховної роботи на рівні куратора. Обгрунтовано терміни «куратор», «тьютор», «ментор», запропоновано авторське визначення поняття «діяльність куратора». Закиентовано увагу на тому, щчо для розвитку високих моральних якостей здобувачів освіти в Одеському начіональному технологічному університеті створено Інститут культури, а також діє Інститут кураторів, що допомагає кураторам академічних груп у роботі зі студентами. Звертається увага на те, щзо виконуючи функиії куратора на факультеті інноваційних технологій харчування і ресторанно-готельного бізнесу, авторка статті приділяє особливу увагу патріотичному вихованню молоді, прищепленню любові до украӥнських традииій та поваги до традицій інших країн. Зазначено, щзо становлення особистості майбутнього фахівия розпочинається на етапі самовизначення, продовжується на етапі самоідентифікаиії, а завершується на етапі самореалізачії.

Ключові слова: куратор, академічна група, функиії куратора, якості куратора, виховна робота, заклад вищуої освіти.

\section{THE ROLE OF AN ACADEMIC GROUP CURATOR IN THE FORMATION OF FUTURE HOTEL AND RESTAURANT BUSINESS SPECIALISTS AS PROFESSIONALS}

\begin{abstract}
The article deals with the role an academic group curator in the formation of future hotel and restaurant business specialists as professionals. The aim of the article was to determine the influence of the academic group curator on the formation of future hotel and restaurant business specialists in the process of vocational training.

The concepts of "curator», "tutor», «mentor» are compared in the article. It is noted that having experience as the academic groups curator in the institutions of different levels of accreditation, the author will consider the academic group curator's activity in the educational process of a university. The viewpoints of domestic and foreign scholars on the phenomenon of advisement, the curator's functions, the curator's qualities, the criteria
\end{abstract}

for effective management of the educational work system at the curator's level of are analyzed. The author provides her own definition of the term "the curator's activity». The academic group curator's activity, is understood as a set of measures aimed at improving students' adaptation process to the university space and to the chosen profession, which is carried out through the curator's functions; constant curator's interaction with the university administration, lecturers, students and their parents.

The article gives the example of the Curators' Institute Activities of the Odessa National Technological University, which helps the academic groups curators in working with the students. It is mentioned that acting as a curator at one of the most numerous Odessa National Technological University faculties, i.e. Innovative Nutrition Technologies, 
Restaurant and Hotel Business, much attention is paid to the students' patriotic education instilling love for Ukrainian traditions and respect for the traditions of other countries. In order to develop high moral qualities, the Institute of Culture has been established at Odessa National Technological University, where lectures on various topics are given and experienced specialists are invited.

It is noted that a professional's personality formation begins at the stage of self-determination, at the second stage (self-identification) there is an identification with the profession (I am a future specialist) and ends at the stage of self-realization (whether this profession is needed for a student). Thus, for students' formation as future professionals requires well-established interaction of all the participants in the educational process. According to the author's position, the curator can act as a mediator between applicants, lecturers and management.

Key words: curator, academic group, curator's functions, curator's qualities, educational work, Higher Education Institution.

Постановка проблеми. У Законі України «Про вищу освіту» зазначається, що «освітній процес $\epsilon$ інтелектуальною, творчою діяльністю у сфері вищої освіти і науки, яка провадиться у закладі вищої освіти (науковій установі) через систему науково-методичних і педагогічних заходів і спрямована на передачу, засвоєння, примноження і використання знань, умінь та інших компетентностей в осіб, які навчаються, а також на формування гармонійно розвиненої особистості» (Закон України «Про вищу освіту», 2014). Як бачимо, важливого значення набуває нині підготовка конкурентоспроможного фахівця, який не лише вміло використовує професійні знання та навички міжособистісної взаємодії, а й любить свою країну і свій народ, зберігає його традиції. У контексті останнього особливої актуальності у закладі вищої освіти $($ далi - 3BO) набуває виховна робота як один зі складників освітнього процесу.

У Концепції розвитку громадянської освіти в Україні зазначається, що «виховний процес повинен бути невід'ємною складовою всього освітнього процесу та орієнтуватися на духовні цінності українського народу (національна самосвідомість, ідентичність, самобутність, гідність, соборність, свобода), загальнолюдські цінності, зокрема морально-етичні (гідність, чесність, справедливість, повага до інституту сім'ї, турбота, повага до себе та інших людей) та соціально-політичні (свобода, демократія, культурне різноманіття, повага до рідної мови та культури, патріотизм, шанобливе ставлення до навколишнього природного середовища, повага до закону, відповідальність та солідарність)» (Концепція розвитку громадської освіти в Україні, 2018).

Як відомо, на ринку України представлено широкий спектр різноманітних спеціальностей (економічні, технічні, технологічні, педагогічні, гуманітарні), за якими здійснюється підготовка майбутніх фахівців. На наш погляд, в умовах сьогодення важливого значення набуває підготовка майбутніх фахівців сфери обслуговування, які працюватимуть за напрямом готельно-ресторанна справа. У процесі підготовки до професійної діяльності відбувається становлення особистості майбутнього фахівця. Особливу роль у цьому процесі відведено куратору академічної групи.

Аналіз наукових досліджень і публікацій. Питання кураторської роботи окреслено в дослідженнях як вітчизняних (І. Бартєнєва, О. Біла, Л. Білоусова, І. Богданова, С. Бричок, І. Бужина, С. Вітвицька, В. Волкова, М. Голубєва, Н. Голярдик, В. Грицанюк, А. Денисенко, А. Жульківська, А. Ільченко, Н. Кузьменко, С. Кучин, О. Лучанінова, Т. Осипова, С. Ольховський, К. Чурпій), так і зарубіжних (Дж. Лодж, Т. Лус, А. Теноріо, Т. Теноріо) науковців, зокрема професійному становленню фахівців присвячені роботи С. Алагманда, С. Амеліної, Ф. Моцафара, Б. Седгпура, С. Хоссейні, Г. Яворської.

Аналіз представлених вище досліджень свідчить, що на сьогодні питанням кураторства загалом і особи куратора академічної групи у становленні майбутніх фахівців сфери обслуговування зокрема приділяється недостатньо уваги, що й спонукало нас до написання означеного дослідження.

Мета статті - схарактеризувати влив куратора академічної групи на становлення майбутніх фахівців готельно-ресторанної справи у процесі професійної підготовки.

Виклад основного матеріалу дослідження. Зважаючи на тему та мету нашого дослідження, передусім схарактеризуємо поняття «куратор», «тьютор», «ментор».

Куратор - це педагогічний працівник, у посадові обов'язки якого входить забезпечення сприятливого перебігу індивідуального розвитку і формування особистості здобувача; внесення необхідних коректив у систему виховання, допомога у вирішенні проблем, що виникають у здобувачів освіти у процесі спілкування між собою, з викладачами, батьками (Крупський, Михалевич, 2010, с. 61). Тьютор - це викладач, робота якого полягає у приділенні особливої уваги навчанню або здоров'ю здобувача / групи здобувачів (Oxford Learner's Dictionaries Online, 2021). Ментор - це особа, яка надає іншій особі, молодшій або менш досвідченій, допомогу або пораду під час роботи чи навчання (Cambridge Dictionary Online, 2021).

Науковці Т. Осипова, I. Бартєнєва, О. Біла, І. Богданова, І. Бужина не виділяють окремо поняття «куратор», «тьютор» та «наставник». Відповідно до їхньої позиції, куратор (тьютор, наставник) студентської академічної групи - це наставник і організатор, вихователь і консультант для здобувачів групи. Він покликаний спрямовувати виховну роботу групи, розвивати в здобувачів активність, самостійність, ініціативу, почуття відповідальності та зацікавленості в навчанні, постійно знаходитися в діловому спілкуванні зі студентською групою, добре знати кожного зі здобувачів освіти, що надає йому можливість впливати як на колектив групи в цілому, так і на кожного студента зокрема (Осипова та ін., 2006, с. 254).

Дослідниця О. Лучанінова зі свого боку зазначає, що відповідно до європейських освітніх стандартів куратор академічної групи виконує сьогодні функції фасилітатора, координатора навчально-виховних дій здобувача освіти, здійснює духовно-культурний супровід становлення його як особистості, тобто є ключовою фігурою суб'єкт-суб'єктних стосунків зі студентом в освітньому 
процесі. Авторка наголошує, що в багатьох вітчизняних закладах вищої освіти викладачі нині наповнюють свою діяльність новим змістом, виконуючи водночас і роль академічного консультанта, тьютора (куратора окремого здобувача або групи здобувачів), куратора освітньої програми. Така його діяльність спрямована передусім на якість освіти. О. Лучанінова також зауважує, що в даному випадку можна спостерігати суперечливу позицію, яку займає певна частина професорсько-викладацького складу закладу освіти: надання тільки освітніх послуг здобувачам і повне заперечення виховного впливу на особистість здобувача. На думку вченої, хибність цієї позиції можна спростувати тим, що сьогодні сама освіта $є$ цінністю. На викладача, який часто виконує ще й функції куратора академічної групи, покладається відповідальність за створення умов для здобувача освіти, аби він прагнув стати професіоналом-особистістю (Лучанінова, 2017, с. 125).

Порівнюючи діяльність куратора академічної групи українського закладу вищої освіти і тьютора британського університету, М. Голубєва та А. Жульківська стверджують, що куратор не тільки є викладачем 3ВО, тобто здійснює власне навчальну діяльність, а також, будучи куратором, впливає на студентську молодь шляхом проведення різноманітних виховних заходів та залучає їі до самовиховання, сприяє становленню доброзичливих, моральних, гуманістичних стосунків серед студентства; виступає посередником у взаємодії вихованців із професорсько-викладацьким складом та керівництвом закладу освіти. Відповідно тьютора можна схарактеризувати як особливу педагогічну посаду, що утворилася історично та забезпечує розробку індивідуальних освітніх програм для учнів і студентів, а також супроводжує їх у процесі індивідуального навчання в школі, закладі вищої освіти, системах додаткової і неперервної освіти (Голубєва, Жульківська, 2012, c. 19).

У зарубіжних дослідженнях під терміном «тьютор» розуміють викладача, ключова функція якого забезпечення основного контакту зі здобувачами освіти, а також здійснення послідовної адміністративної, академічної та кар'єрної діяльності, використовуючи новітні методи та технології з метою налагодження взаємодії здобувачів із викладачами та навчальним закладом (Lodge, 2012, с. 16).

Маючи чималий досвід роботи куратором академічних груп у закладах вищої освіти різних рівнів акредитації, у нашому дослідженні ми розглядатимемо саме діяльність куратора академічної групи в освітньому процесі ЗВО.

Аналізуючи терміни «куратор» та «кураторство», дослідники висловлюють стосовно них різні погляди. Так, К. Чурпій зазначає, що куратор академічної групи у закладі вищої освіти - це викладач із відповідним досвідом виховної роботи, життєвим досвідом, вихователь із широким кругозором і рисами лідера. Робота викладача-куратора $з$ групою відбувається 3 використанням комплексного підходу для вирішення конкретно поставлених завдань, використовуючи різні форми виховання і досягнення мети, як-от: проведення бесід, екскурсій, наведення прикладів із життя видатних людей тощо (Чурпій, 2013, с. 103).
Виховна робота куратора групи передбачає наявність кількох блоків, які втілюються одночасно та взаємопов'язані між собою, зокрема:

1. Виховання патріотизму - передбачає створення чітких орієнтирів національної самовідданості студентів, залучення до вивчення і примноження багатих традицій національної інтелігенції, розвиток української нації, іiї історичної свідомості, традицій, української науки та культури.

2. Навчально-виховна робота - передбачає важливість отримання належної освіти, передача любові до предмета, який викладає (якщо куратор викладає у своїй групі).

3. Психолого-педагогічна робота - планується куратором, зважаючи на аналіз її результатів.

4. Науково-методична робота - будується на основі постійного педагогічного та наукового пошуку (залучення здобувачів до участі у наукових гуртках, підготовка до виступів на наукових конференціях) (Чурпій, 2013, с. 103-104).

За визначенням Н. Кузьменко, куратор має значний виховний вплив на формування професійної зацікавленості здобувачів та пов'язані з ним самоствердження та самоактуалізацію, сприяє розвитку знань і навичок, формуванню світогляду. Єдність групи, на думку науковця, буде лише за умови, якщо куратор зможе сформувати в студентів позитивне ставлення одне до одного, дружні стосунки в колективі, доброзичливу атмосферу, що сприяють повноцінному процесу здобування освіти (Кузьменко, 2015 с. 330).

А. Ільченко зі свого боку стверджує, що виховна робота куратора в студентській академічній групі являє собою цілісний і впорядкований комплекс закономірно побудованих, взаємопов'язаних компонентів, які у своїй сукупності сприяють професійному становленню і розвитку особистості, формуванню їі життєвої позиції, набуттю вмінь самостійної роботи і роботи в колективі (Ільченко, 2017, с 41).

Аналізуючи діяльність куратора академічної групи, В. Левченко в особі куратора вбачає викладача або співробітника освітньої установи, прикріпленого до конкретної навчальної групи 3 метою спостереження й контролю за процесом навчальної й позанавчальної діяльності здобувачів освіти та надання їм за потреби інформаційно-організаційної і психолого-педагогічної допомоги у вирішенні різноманітних питань. На думку науковця, діяльність куратора насамперед зорієнтована на вирішення ключового завдання - підтримати й посилити мотивацію здобувачів на одержання професійної освіти, сприяти їхній активній участі в освітньому процесі (Левченко, 2013, с. 126). Ми погоджуємося із позицією автора в тому, що куратор - це ключова ланка в роботі з адаптації здобувачів освіти до нового освітньо-виховного середовища, тобто він поєднує вихователів і вихованців, виступає посередником між адміністрацією факультету та закладу вищої освіти й студентською групою, родиною здобувача, педагогічним колективом і студентом.

Суголосну позицію щодо адаптації студентської молоді до простору 3ВО та обраного фаху виявили Л. Білоусова та Є. Ольховський. Відповідно до їхньої позиції робота куратора із першокурсниками 
спрямована на вирішення різнопланових проблем адаптації здобувачів, зокрема: до нових умов навчання і життя, до нового оточення, нових завдань, пов'язаних iз набуттям професійної компетентності (Білоусова, Ольховський, 2012, с. 40).

Дослідниця В. Волкова зазначає, що основними завданнями куратора на початковому етапі формування професійних інтересів $\epsilon$ : виявлення у здобувачів освіти мотивів вступу в конкретний навчальний заклад, міри розуміння специфіки і характеру обраної професії; визначення міри свідомості вибору навчального закладу і професії, діагностика даних, які можуть і мають бути розвинуті в процесі підготовки майбутніх фахівців (Волкова, 2014, с. 165).

У сучасних умовах закладу вищої освіти куратор здійснює роботу щодо зміни негативного соціального статусу студентів у групі завдяки діагностичній, тренінговій, просвітницькій, профілактичній та консультативній роботі. Така робота передбачає вивчення психолого-педагогічних особливостей здобувача освіти та його мікросередовища, умов проживання, виявлення інтересів і потреб, труднощів і проблем, надання йому соціальної допомоги і підтримки, реалізації прав і свобод, створення комфортної і безпечної обстановки, забезпечення охорони життя і здоров'я. Робота зі здобувачами освіти з негативним соціальним статусом повинна передбачати особливу систему соціально-педагогічної допомоги команди фахівців, що включає куратора, батьків, психолога, викладачів, якій впоратися із проблемними питаннями буде набагато легше, якщо діяти спільно (Бричок, 2016, с. 87)

Досліджуючи конфлікти серед здобувачів, А. Теноріо, Т. Лус та Т. Теноріо зазначають, що вихователь, тобто підготовлений викладач, як правило, виступає посередником, стороннім аутсайдером, який, проте, допомагає тим, хто вирішує конфлікт самостійно. Посередники не нав'язують нікому своїх рішень і не стають на бік жодної зі сторін. Однак вони допомагають віднайти альтернативу, щоб створити атмосферу поваги та співпраці, відновити спілкування та дружні стосунки (Tenorio, Loos, Tenorio, 2017).

Для попередження девіантної поведінки студентів групи важливого значення набуває вивчення особистості кожного з них. Пропонуємо таку орієнтовну програму вивчення особистості здобувача освіти:

1. Загальні відомості (назва закладу загальної середньої освіти і рік закінчення; сімейний стан; де і ким працюють батьки; стан здоров'я).

2. Загальний рівень розвитку (фізичний та інтелектуальний розвиток; ставлення до навчання, успішність; ставлення до фізичної праці; рівень дисципліни; інтереси і нахили).

3. Громадська діяльність (участь у громадському житті закладу освіти, характер громадської діяльності; місце здобувача серед студентів групи).

4. Основні риси особистості (моральні якості; риси характеру; особливості темпераменту) (Бричок, 2016, c. 86).

Із метою становлення студентів як фахівців, важливим є дотримання куратором певних функцій, а саме:

- виховної функції - вплив на формування емоційних, вольових, інтелектуальних та фізичних якостей студентів, спираючись на систему різноманітних виховних заходів;

- організаторської функції - ініціювання куратором виховних заходів, стимуляції та мотивації, організації та контролю;

- координаційної функції - узгодження діяльності групи із деканатом, кафедрами, ректоратом;

- соціально-спрямовувальної функції - скеровування виховних заходів на формування наукового світогляду здобувачів, професійних якостей та активної життєвої позиції;

- дослідно-аналітичної функції - діагностування рівнів вихованості особистості, вивчення мотивів, інтересів та потреб навчальної та пізнавальної діяльності здобувачів, соціально-побутових умов життя, стану здоров'я, рівня успішності тощо; вивчення внутрішнього світу і можливостей вихованців, складання програм їхнього розвитку;

- інформаційної функції - уміння куратора акумулювати знань із теорії та методики виховного процесу, бути гарним вихователем, взірцем педагогічного досвіду, авторитетним порадником у процесі пошуку різноманітної інформації, наставником із будь-яких проблемних питань;

- соціальної функції - вивчення куратором об'єктивних і суб'єктивних чинників, що впливають на розвиток особистості; кореляція навичок соціальної поведінки, спрямованої на успішне входження студентської молоді до структури сучасного життя і виробництва;

- спрямовувальної (морально-виховної) функції - спрямування здобувачів освіти на життєвий вибір згідно з моральними і правовими нормами, формування гуманних взаємостосунків у студентському середовищі, збагачення їхнього досвіду історичними та життєвими прикладами, що варті наслідування;

- стимулювальної функції - створення атмосфери психолого-педагогічної підтримки в групі, що сприяє самоствердженню молодої людини, реалізації іiї потенційних можливостей;

- координаційної функції - здатність куратора групи спрямувати виховні зусилля педагогів, батьків, представників громадськості на позитивні результати у вихованні студентської молоді;

- комунікативної функції - створення доброзичливого мікроклімату в групі, забезпечення позитивних змін у міжособистісних стосунках (Голубєва, Жульківська, 2012, с. 20; Кучин, 2017) .

Для виконання окреслених вище функцій важливого значення набувають особисті якості куратора. На нашу думку, ключовими серед них $є$ компетентність і комунікабельність.

Компетентність куратора стосується його особистісних рис, умінь і навичок, а також передбачає наявність не лише достатнього професійного досвіду роботи в закладі вищої освіти, а й не менше ніж рік роботи в тому закладі, в якому йому доручено курувати групу студентів. Ми підтримуємо позицію Б. Грицанюк стосовно того, що куратор повинен бути фахівцем того профілю, який здобувають його підопічні, а також обов'язково викладати один із лекційних курсів чи проводити семінарські / практичні заняття в академічній групі. На жаль, практика та власний досвід роботи 
свідчать, що це не завжди так. Крім того, компетентність передбачає системність мислення та наявність організаторських якостей, які є наслідком вияву певних психологічних властивостей особистості. Наприклад, такі якості, як психологічна вибірковість, психологічний такт, здатність «заражати» власною позитивною енергією інших людей, активізувати їх до дій, вимогливість тощо, забезпечують виконання організаторської функції куратора, яка полягає в організації пізнавальної, трудової, естетичної діяльності здобувачів освіти (Грицанюк, 2013, с. 209).

До важливих особистісно-ділових, професійних якостей куратора варто віднести: стійкість до стресу (здатність протистояти сильним негативним емоціогенним впливам, що викликають значну психічну напругу); морально-етичні якості (чесність, порядність, принциповість, обов'язковість, вірність слову, самокритичність, гуманність, тактовність, справедливість, цілеспрямованість, альтруїзм, бездоганна моральність, енергійність, оптимістичність, вимогливість до себе та інших, почуття гумору, толерантність, уміння йти на компроміс та ін.); підприємницькі якості (уміння передбачати й швидко оцінювати ситуацію) (Грицанюк, 2013, c. 209)

Ми переконані, що куратор - це ключовий ланцюг у системі управління виховною діяльністю закладу вищої освіти. Це підтверджує С. Вітвицька, виокремлюючи критерії ефективності управління системою виховної роботи на рівні куратора академічної групи: рівень вихованості майбутніх фахівців; активність, згуртованість групи, суспільно-корисний характер iï діяльності; стабільний режим роботи академічної групи, відсутність серйозних випадків; порушення трудової та навчальної дисципліни студентами; позитивна мотивація освітньої діяльності здобувачів освіти, що виявляється у навчально-пізнавальній, науково-дослідній, інших видах діяльності; мікроклімат у групі, що сприяє самореалізації особистості кожного студента; різноманітність форм виховної позааудиторної роботи, що сприяє самореалізації особистості студентської молоді; діяльність студентського самоврядування в групі; участь групи у загальноакадемічних заходах; сприятливі умови проходження студентами адаптаційного періоду першого курсу; оволодіння здобувачами освіти досвідом соціальної поведінки (Вітвицька, 2005, с. 151).

Отже, під діяльністю куратора академічної групи будемо розуміти комплекс заходів, спрямований на покращення процесу адаптащії здобувачів до простору закладу вищої освіти та обраного фаху, який здійснюється завдяки виконанню куратором своӥх функиій, а також постійну взаємодію куратора з адміністраиією закладу освіти, викладачами, студентами та їхніми батьками.

В Україні кожен заклад вищої освіти має своє положення про кураторство. Так, в Одеському національному технологічному університеті (раніше - Одеська наиіональна академія харчових технологій (ОНАХТ) - М. Ш.) нині діє Положення про Інститут кураторства, що базується на Конституції України, Законах України «Про освіту» та «Про вищу освіту», Концепції виховної роботи і фізичного розвитку студентів та викладачів Одеської національної академії харчових технологій, статуті Одеського національного технологічного університету та інших нормативно-правових актах (Концепція виховної роботи і фізичного розвитку студентів та викладачів ОНАХТ, 2018, с. 1).

Основними завданнями Інституту кураторів є:

1. Виховання патріотизму та високої духовності, формування активної життєвої та громадянської позиції, самосвідомості майбутнього фахівця.

2. Надання допомоги здобувачам в освітньому процесі, науковій роботі, міжособистісних стосунках, організації побуту в гуртожитках тощо.

3. Сприяння гармонійному розвитку особистості здобувачів шляхом залучення їх до різноманітних заходів місцевого та державного рівнів, а також ті, що відбуваються в закладі освіт.

4. Охорона та зміцнення здоров'я студентів.

5. Спонукання майбутніх фахівців до активної протидії корупції, зловживанню службовим становищем та іншими правопорушеннями (Концепція виховної роботи і фізичного розвитку студентів та викладачів ОНАХТ, 2016, с. 2).

У Положенні про Інститут кураторів особлива увага приділяється передусім обов'язкам та правам куратора. Так, робота кураторів академічних груп спрямована на: виховання у здобувачів освіти патріотизму та любові до Батьківщини; забезпечення знання студентами корпоративного кодексу Одеського національного технологічного університету; проведення кураторських годин; проведення інструктажів із техніки безпеки; вивчення індивідуальних особливостей здобувачів освіти; виховання інтересу до обраної спеціальності; відвідування гуртожитків із метою перевірки дотримання правил внутрішнього розпорядку та ін. Куратори мають право: вивчати досвід інших кураторів, надавати пропозиції до адміністрації закладу освіти щодо покращення освітнього процесу, брати участь у розгляді освітніх питань (Концепція виховної роботи і фізичного розвитку студентів та викладачів ОНАХТ, 2018, с. 3).

Починаючи роботу із групою, кожен куратор проводить анкетування студентів із метою виявлення активу групи, знайомства з родинами здобувачів, виявлення пільгових категорій студентів, а також визначення проблем, які можуть виникнути у процесі навчання в закладі.

Iз метою поліпшення процесу адаптації здобувачів до простору закладу вищої освіти та обраного фаху на рівні університету загалом та факультету зокрема проводяться різноманітні заходи. Так, на загальноакадемічному рівні здобувачі освіти брали учать у таких заходах, як «Посвячення в першокурсники», «Туристичний перехід та встановлення рекорду України», «Святкування дня народження університету». На рівні факультету проводяться загальнокураторські години, зустрічі із видатними особистостями та вченими.

Виконуючи функції куратора на одному із найчисельніших факультетів Одеського національного технологічного університету - факультеті інноваційних технологій харчування і ресторанно-готельного бізнесу, значну увагу приділяємо патріотичному вихованню студентської молоді, прищеплюємо їй любов до українських традицій та повагу до традицій інших країн, адже, на нашу думку, майбутні ресторатори та 
готельєри повинні знати не лише власні традиції, а й традиції та звичаї інших країн.

Крім того, проводяться кураторські години, теми яких неабияк зацікавлюють сучасну молодь: «День Незалежності України», «День народження Одеси», «Річниця Героїчної оборони Одеси», «Історія мого навчального закладу», «День захисника України», «День Соборності України», «10 квітня - День визволення Одеси від фашистських загарбників», «9 травня - День Перемоги», «День пам'яті жертв Голокосту», «День пам'яті жертв Голодомору», «День пам'яті Чорнобиля», «Вишиванка - код нації» та ін.

Переконані, що важливу роль у формуванні особистості студентів-рестораторів та готельєрів належить знанням правил техніки безпеки, вмінню надати першу медичну допомогу. У зв'язку з цим постійно проводяться інструктажі з техніки безпеки, навчання щодо надання першої медичної допомоги, до яких долучаються відповідні фахівці та медики.

Задля розширення кругозору та розвитку духовності майбутніх фахівців в Одеському національному технологічному університеті діє Інститут культури. Упродовж навчального року кожен викладач готує 1-2 лекції-презентації на тему за вибором. Наприклад, мені як куратору та моїй групі студентів цікаво було прослухати лекції, присвячені визначним місцям України та світу, літературі та користі від читання, правильному харчуванню та ін.

Лекції в Інституті культури, зокрема на факультеті інноваційних технологій харчування і ресторанно-готельного бізнесу, проводять не лише викладачі закладу, а й відомі ресторатори, шеф-кухарі, готельєри. Мета таких зустрічей - ознайомити студентів із «секретами» обраного ними фаху, надати рекомендації, аби у майбутньому вони могли стати справжніми професіоналами своєї справи.

У минулому році пандемія COVID-19 внесла свої корективи в освітній процес Одеського національного технологічного університету. Зважаючи на це, усі зазначені вище заходи (кураторські години та події) проводилися онлайн із використанням платформи Zoom.

Таким чином, становлення особистості майбутнього фахівця готельно-ресторанної справи включає три етапи: перший - етап самовизначення, коли в здобувача освіти складається уявлення про майбутню професію; другий - етап самоідентифікаиіï, на якому відбувається ототожнення себе із професією (Я-майбутній фахівець); третій - етап самореалізації (Чи потрібен мені цей фах?). Варто зауважити, що в процесі становлення здобувачів як майбутніх професіоналів необхідна злагоджена взаємодія всіх учасників освітнього процесу (студентів, викладачів та керівництва закладу освіти / факультету).

Висновки. Виховна робота у закладі вищої освіти - важлива складова формування не лише конкурентоспроможного фахівця, а й гармонійно розвиненої особистості. Ключовою ланкою у становленні майбутнього фахівця є куратор академічної групи, якому відведена особлива роль - виховання патріотизму та високих моральних і духовних якостей здобувача освіти; формування його життєвої і громадської позиції; прищеплення любові до українських традицій та поваги до традицій інших країн; посередництво між усіма учасниками освітнього процесу.

Перспективи подальших досліджень. Подальших пошуків у даному напрямі вимагає питання щодо ролі куратора академічної групи в розвитку академічної доброчесності студентської молоді як запоруки майбутньої успішної професійної діяльності.

\section{СПИСОК ВИКОРИСТАНОЇ ЛІТЕРАТУРИ}

Про вищу освіту: Закон України від 01.07.2014 p. № 1556-VII . URL: https://zakon.rada.gov.ua/laws/ show/1556-18/ed20140701\#Text (дата звернення: 06.07.2021).

Про схвалення Концепції розвитку громадської освіти в Україні: розпорядження Кабінету Міністрів України від 03.10.2018 р. № 710-p. URL: https://zakon. rada.gov.ua/laws/show/710-2018-\%D1\%80\#Text (дата звернення: 06.07.2021).

Крупський, Я. В., Михалевич, В. М. (2010). Тлумачний словник з інформаційно-педагогічних технологій / МОН України; Вінниц. нац. техн. ун-т. Вінниця: ВНТУ. 72 c. URL: http://irbis-nbuv.gov.ua/cgi-bin/ua/elib.exe?Z21 $\mathrm{ID}=\& \mathrm{I} 21 \mathrm{DBN}=\mathrm{UKRLIB} \& \mathrm{P} 21 \mathrm{DBN}=\mathrm{UKRLIB} \& \mathrm{~S} 21 \mathrm{STN}=$ $1 \& \mathrm{~S} 21 \mathrm{REF}=10 \& \mathrm{~S} 21 \mathrm{FMT}=$ online book $\& \mathrm{C} 21 \mathrm{COM}=\mathrm{S} \& \mathrm{~S} 2$ $1 \mathrm{CNR}=20 \& \mathrm{~S} 21 \mathrm{P} 01=0 \& \mathrm{~S} 21 \mathrm{P} 02=0 \mathrm{C} 21 \mathrm{P} 03=\mathrm{FF}=\& \mathrm{~S} 21 \mathrm{ST}$ $\mathrm{R}=\mathrm{ukr0003917}$ (дата звернення: 16.06.2021).

Oxford Learner's Dictionaries website. URL: https:// www.oxfordlearnersdictionaries.com (дата звернення: 16.06.2021).

Cambridge English Dictionary: website. URL: https:// dictionary.cambridge.org/dictionary/english (дата звернення: 16.07.2021).

Осипова, Т. Ю., Бартєнєва, І. О., Біла, О. О. та ін. (2006). Виховна робота зі студентською молоддю: навчальний посібник / Південноукр. держ. пед. ун-т ім. К. Д. Ушинського; за ред. Т. Ю. Осипової. Одеса: Фенікс. 288 с.

Лучанінова, О. П. (2017). Куратор академічної групи як ключовий суб'єкт виховної системи ВТНЗ. Духовність особистості: методологія, теорія і практика. Вип. 1. С. 120-132. URL: http://nbuv.gov.ua/UJRN/ domtp_2017_1_15 (дата звернення: 18.06.2021).

Голубєва, М. О., Жульківська, А. М., (2012). Порівняльна характеристика діяльності куратора академічної групи українського ВНЗ і тьютора британського університету. Наукові записки НаУКМА. Педагогічні, психологічні науки та соиіальна робота. Київ: НаУКМА T. 136. C. 19-22. URL: http://nbuv.gov.ua/UJRN/ NaUKMApp_2012_136_5 (дата звернення: 18.06.2021).

Lodge, J. (2012). Implementing a Principal Tutor to Increase Student Engagement and Retention within the First Year of a Professional Program. The International Journal of the First Year in Higher Education. № 3 (1). URL: https://doi.org/10.5204/intjfyhe.v3i1.101 (дата звернення: 14.06.2021).

Чурпій, К. Л. (2013). Роль викладача-куратора у виховній роботі зі студентами. Медична освіта. Тернопіль: ТДМУ. № 1. С. 103-104. URL: http://nbuv.gov.ua/UJRN/ Mosv 2013135 (дата звернення: 06.07.2021).

Кузьменко, Н. В. (2015). Педагогічна взаємодія в стосунках «куратор - студенти» в контексті позааудиторної виховної роботи. Педагогіка та психологія. 
Харків: ХНПУ ім. Г. С. Сковороди. Вип. 49. С. 327-335. URL: http://nbuv.gov.ua/UJRN/znpkhnpu_ped_2015_49_35 (дата звернення: 14.06.2021).

Ільченко, А. А. (2017). Діяльність куратора на етапі адаптації студентів у вищому навчальному закладі. Збірник наукових праць [Херсонського державного університету]. Педагогічні науки. Херсон: ХДУ. Вип. 75 (2). С. 39-43. URL: http://nbuv.gov.ua/UJRN/ znppn 2017_75(2) 9 (дата звернення: 06.07.2021).

Левченко, В. Ю. (2013). Становлення інституту кураторства у вітчизняній педагогічній думці. Засоби навчальної та науково-дослідної роботи. Харків: ХНПУ ім. Г. С. Сковороди. Вип. 40. С. 122-128. URL: http:// nbuv.gov.ua/UJRN/znpkhnpu_zntndr_2013_40_15 (дата звернення: 12.06.2021).

Білоусова, Л. І., Ольховський, Є. О. (2012). Специфіка і складники успішності виховної роботи куратора 3 першокурсниками. Педагогічний дискурс. Хмельницький: ХГПА. Вип. 12. С. 38-42. URL: http://nbuv.gov.ua/ UJRN/0peddysk_2012_12_8 (дата звернення126.06.2021).

Волкова, В. (2014). Роль куратора у соціально-психологічній адаптації студентів-першокурсників. Педагогіка і психологія професійної освіти. № 2. С. 162-168. URL: http://nbuv.gov.ua/UJRN/Pippo_2014_2_19 (дата звернення: 10.07.2021).

Бричок, С. Б. (2016). Психолого-педагогічна діагностика у роботі куратора студентської групи. Інноватика у вихованні. Рівне: РДГУ. Вип. 3. С. 82-89. URL: http://nbuv.gov.ua/UJRN/inuv_2016_3_11 (дата звернення 10.07.2021).

Tenorio, A., Loos, T., Tenorio, T., (2017). Perceptions of tutors and students on affectivity and conflict mediation in an e learning course for the Brazilian police. Percepciones de tutores y alumnos acerca de la afectividad en la mediación de conflictos en un curso a distancia de la policía. RIED. Revista Iberoamericana de Educación a Distancia. № 20 (1). P. 223. URL: https://doi.org/10.5944/ried.20.1.15806 (дата звернення 14.06.2021).

Кучин, С. П. (2017) Удосконалення реалізації виховної функції інституту кураторства як пріоритет упровадження механізмів державного регулювання в сфері освіти. Державне управління: удосконалення та розвиток: електронне наукове видання. № 1. URL: http://nbuv.gov.ua/UJRN/Duur_2017_1_5 (дата звернення: 12.06.2021).

Грицанюк, В. В. (2013). Особисті якості куратора як важлива складова ефективності навчально-виховного процесу. Вісник Львівського державного університету безпеки життєдіяльності. Львів: ЛДУБЖД. № 8. C. 209-212. URL: http://nbuv.gov.ua/UJRN/ Vldubzh 2013833 (дата звернення: 12.06.2021).

Вітвицька, С. С. (2005). Основи педагогіки вищої школи: методичний посібник. Київ: Центр навчальної літератури. 396 с.

Положення про Інститут кураторів Одеської національної академії харчових технологій: наказ від 27.06.2018 p. № 268-01. URL: https://www.onaft.edu.ua/ download/pubinfo/position_institute_268-01_27.06.18.pdf (дата звернення: 06.07.2021).

Про введення в дію Концепції виховної роботи і фізичного розвитку студентів та викладачів Одеської національної академії харчових технологій: наказ від 18.08.2016 р. № 201-01. URL: https://www.onaft.edu. ua/download/pubinfo/concept_educ_work_phys_devel.pdf (дата звернення: 06.07.2021)

\section{REFERENCES}

Pro vyshchu osvitu: Zakon Ukrainy [On High Education: Law of Ukraine]: vid 01.07.2014 r. № 1556-VII. URL: https:// zakon.rada.gov.ua/laws/show/1556-18/ed20140701\#Text (data zvernennia: 06.07.2021). [in Ukrainian].

Kontseptsia rozvytku hromadskoi osvity v Ukraini [The concept of public education development in Ukraine]: vid 03.10.2018 r. № 710-r. URL: https://zakon.rada.gov. ua/laws/show/710-2018-\%D1\%80\#Text (data zvernennia: 06.07.2021). [in Ukrainian].

Krupskyi, Ya. V., Mykhalevych, V. M. (2010). Tlumachnyi slovnyk z informatsiino-pedahohichnykh tekhnolohii [Explanatory dictionary of information and pedagogical technologies] / MON Ukrainy; Vinnyts. nats. tekhn. un-t. Vinnytsia: VNTU. 72 c. URL: http://irbis-nbuv.gov.ua/ cgi-bin/ua/elib.exe?Z21ID $=\& I 21 \mathrm{DBN}=$ UKRLIB\&P21DB$\mathrm{N}=\mathrm{UKRLIB} \& \mathrm{~S} 21 \mathrm{STN}=1 \& \mathrm{~S} 21 \mathrm{REF}=10 \& \mathrm{~S} 21 \mathrm{FMT}=$ online book\&C21COM=S\&S21CNR $=20 \& S 21 \mathrm{P} 01=0 \& S 21 \mathrm{P}$ $02=0 \& S 21 \mathrm{P} 03=\mathrm{FF}=\& S 21 \mathrm{STR}=\mathrm{ukr} 0003917$ (data zvernennia: 16.06.2021). [in Ukrainian].

Oxford Learners Dictionaries website. URL: https:// www.oxfordlearnersdictionaries.com (data zvernennia: 16.06.2021). [in English].

Cambridge English Dictionary: website. URL: https:// dictionary.cambridge.org/dictionary/english (data zvernennia: 16.07.2021). [in English].

Osypova, T. Yu., Bartienieva, I. O., Bila, O. O. ta in. (2006). Vykhovna robota zi studentskoiu moloddiu: navchalnyi posibnyk [Educational work with student youth: textbook] / Pivdennoukr. derzh. ped. un-t im. K. D. Ushynskoho; za red. T. Yu. Osypovoi. Odesa: Feniks. 288 s. [in Ukrainian].

Luchaninova, O. P. (2017). Kurator akademichnoi hrupy yak kliuchovyi subiekt vykhovnoi systemy VTNZ [Tutor of the academic group as a key subject of pedagogic system of higher technical educational establishment]. Dukhovnist osobystosti: metodolohiia, teoriia $i$ praktyka. Vyp. 1. S. 120-132. URL: http://nbuv.gov.ua/ UJRN/domtp_2017_1_15 (data zvernennia: 18.06.2021). [in Ukrainian].

Holubieva, M. O., Zhulkivska, A. M., (2012). Porivnialna kharakterystyka diialnosti kuratora akademichnoi hrupy ukrainskoho VNZ i tiutora brytanskoho universytetu [Comparative characteristic of the activity of a curator of an academic group in Ukrainian establishment of higher learning and a tutor in a British University]. Naukovi zapysky NaUKMA. Pedahohichni, psykholohichni nauky ta sotsialna robota. Kyiv: NaUKMA T. 136. S. 19-22. URL: http://nbuv.gov.ua/UJRN/NaUKMApp 20121365 (data zvernennia: 18.06.2021). [in Ukrainian].

Lodge, J. (2012). Implementing a principal tutor to increase student engagement and retention within the first year of a professional program. The International Journal of the First Year in Higher Education. № 3 (1). URL: https://doi.org/10.5204/intjfyhe.v3i1.101 (data zvernennia: 14.06.2021). [in English].

Churpii, K. L. (2013). Rol vykladacha-kuratora u vykhovnii roboti zi studentamy [The role of teacher-supervisor 
in educational work with students]. Medychna osvita. Ternopil: TDMU. № 1. S. 103-104. URL: http://nbuv.gov.ua/ UJRN/Mosv 2013 1 35 (data zvernennia: 06.07.2021). [in Ukrainian].

Kuzmenko, N. B. (2015). Pedahohichna vzaiemodiia v stosunkakh «kurator -studenty» v konteksti pozaaudytornoi vykhovnoi roboty [Pedagogical interaction in the relationship «Curator-Students» in the Context of extracurricular educational work]. Pedahohika ta psykholohiia. Kharkiv: KhNPU im. H. S. Skovorody. Vyp. 49. S. 327-335. URL: http://nbuv.gov.ua/UJRN/znpkhnpu_ped_2015_49_35 (data zvernennia: 14.06.2021). [in Ukrainian].

Ilchenko, A. A. (2017). Diialnist kuratora na etapi adaptatsii studentiv u vyshchomu navchalnomu zakladi [Curator's activity at the stage of students' adaptation in a higher educational institution]. Zbirnyk naukovykh prats [Khersonskoho derzhavnoho universytetu]. Pedahohichni nauky. Kherson: KhDU. Vyp. 75 (2). S. 39-43. URL: http://nbuv.gov.ua/UJRN/znppn_2017_75(2)_9 (data zvernennia: 06.07.2021). [in Ukrainian].

Levchenko, V. Yu. (2013). Stanovlennia instytutu kuratorstva u vitchyznianii pedahohichnii dumtsi [The curatorship institute formation in the national pedagogical thought]. Zasoby navchalnoi ta naukovo-doslidnoi roboty. Kharkiv: KhNPU im. H. S. Skovorody. Vyp. 40. S. 122-128. URL: http://nbuv.gov.ua/UJRN/znpkhnpu zntndr $2013 \quad 40 \quad 15$ (data zvernennia: 12.06.2021). [in Ukrainian]

Bilousova, L. I., Olkhovskyi, Ye. O. (2012). Spetsyfika i skladnyky uspishnosti vykhovnoi roboty kuratora z pershokursnykamy [Specificity and components of successful educational work of a curator with first year students]. Pedahohichnyi dyskurs. Khmelnytskyi: KhHPA. Vyp. 12. S. 38-42. URL: http://nbuv.gov.ua/UJRN/0peddysk $2012 \quad 128$ (data zvernennia126.06.2021). [in Ukrainian].

Volkova, V. (2014). Rol kuratora u sotsialno-psykholohichnii adaptatsii studentiv-pershokursnykiv [The role of the curator in the social and psychological adaptation of first year students]. Pedahohika i psykholohiia profesiinoi osvity. № 2. S. 162-168. URL: http://nbuv.gov.ua/ UJRN/Pippo_2014_2_19 (data zvernennia: 10.07.2021). [in Ukrainian].

Brychok, S. B. (2016). Psykholoho-pedahohichna diahnostyka u roboti kuratora studentskoi hrupy [Psychological and pedagogical diagnostics in the work of a student group curator]. Innovatyka $u$ vykhovanni. Rivne: RDHU. Vyp. 3. S. 82-89. URL: http://nbuv.gov.ua/ UJRN/inuv 2016311 (data zvernennia 10.07.2021). [in Ukrainian].
Tenorio, A., Loos, T., Tenorio, T., (2017). Perceptions of tutors and students on affectivity and conflict mediation in an e learning course for the Brazilian police. Percepciones de tutores y alumnos acerca de la afectividad en la mediación de conflictos en un curso a distancia de la policía. RIED. Revista Iberoamericana de Educación a Distancia. № 20 (1). P. 223. URL: https://doi.org/10.5944/ ried.20.1.15806 (data zvernennia 14.06.2021). [in Spanish].

Kuchyn, S. P. (2017) Udoskonalennia realizatsii vykhovnoi funktsii instytutu kuratorstva yak priorytet uprovadzhennia mekhanizmiv derzhavnoho rehuliuvannia $\mathrm{v}$ sferi osvity [Improving the implementation of the educational function of the supervision institute as a priority of the mechanisms implementation of state regulation in the sphere of education]. Derzhavne upravlinnia: udoskonalennia ta rozvytok: elektronne naukove vydannia. № 1. URL: http://nbuv.gov.ua/UJRN/Duur_2017_1_5 (data zvernennia: 12.06.2021). [in Ukrainian].

Hrytsaniuk, V. V. (2013). Osobysti yakosti kuratora yak vazhlyva skladova efektyvnosti navchalno-vykhovnoho protsesu [Personal qualities of a curator as an important component of educational process effectiveness]. Visnyk Lvivskoho derzhavnoho universytetu bezpeky zhyttiediialnosti. Lviv: LDUBZhD. № 8. S. 209-212. URL: http:// nbuv.gov.ua/UJRN/Vldubzh_2013_8_33 (data zvernennia: 12.06.2021). [in Ukrainian].

Vitvytska, S. C. (2005). Osnovy pedahohiky vyshchoi shkoly: metodychnyi posibnyk [Fundamentals of Higher School Pedagogy: methodological guideline]. Kyiv: Tsentr navchalnoi literatury. 396 c. [in Ukrainian].

Polozhennia pro Instytut kuratoriv ONAKhT [Regulations on the Institute of Curators of ONAFT]: nakaz vid 27.06.2018 r. № 268-01. URL: https://www.onaft.edu.ua/ download/pubinfo/position institute 268-01 27.06.18.pdf (data zvernennia: 06.07.2021). [in Ūkrainian].

Pro vvedennia v diiu Kontseptsii vykhovnoi roboty $\mathrm{i}$ fizychnoho rozvytku studentiv ta vykladachiv ONAKhT [On Introducing the Concept of Educational Work and Physical Development of Students and Teachers of the Odessa National Academy of Food Technologies]: nakaz vid 18.08.2016 r. № 201-01. URL: https://www.onaft.edu. ua/download/pubinfo/concept educ_work_phys_devel.pdf (data zvernennia: 06.07.2021). [in Ukrainian].

Дата надходження до редакиії 28.08.2021 p. 